\title{
NEW INEQUALITIES FOR SOME GENERALIZED MATHIEU TYPE SERIES AND THE RIEMANN ZETA FUNCTION
}

\section{H. M. Srivastava, Khaled MehreZ and ŽIVORad Tomovski}

Abstract. Our aim in this paper is to derive several new inequalities for the Mathieu type series and the Riemann zeta function. In particular, we prove Turán type inequalities and some monotonicity and log-convexity results for these special functions. New Laplace type integral representations for the Mathieu type series and the Riemann zeta function are also presented.

Mathematics subject classification (2010): Primary 33B15, 33E20, secondary 11M35, 60E10.

Keywords and phrases: Mathieu series, generalized Mathieu series, Riemann zeta function, inequalities, Bessel function, Mellin and Laplace integral representations, Turán type inequalities.

\section{REFERENCES}

[1] H. Alzer, J. L. Brenner And O. G. Ruehr, On Mathieu's inequality, J. Math. Anal. Appl. 218 (1998), 607-610.

[2] P. Cerone, Bounding Mathieu type series, RGMIA Res. Rep. Coll. 6 (3) (2003), Article ID 7, 1-12.

[3] P. CERone AND C. T. LENARD, On integral forms of generalised Mathieu series, JIPAM J. Inequal. Pure Appl. Math. 4 (5) (2003), Article ID 100, 1-11 (electronic).

[4] J. Choi AND H. M. SRIVAStava, Mathieu series and associated sums involving the Zeta function, Comput. Math. Appl. 59 (2010), 861-867.

[5] J. Choi And H. M. SRivastava, The Clausen function $\mathrm{Cl}_{2}(x)$ and its related integrals, Thai J. Math. 12 (2014), 251-264.

[6] L. Debnath and D. Bhatta, Integral Transforms and Their Applications, Third edition, Chapman and Hall (CRC Press), Taylor and Francis Group, London and New York, 2014.

[7] N. Elezović, H. M. SRIVASTAVA AND Ž. TOMOVSKI, Integral representations and integral transforms of some families of Mathieu series, Integral Transforms Spec. Funct. 19 (2008), 481-495.

[8] O. Emersleben, Über die Reihe $\sum_{k=1}^{\infty} k /\left(k^{2}+r^{2}\right)^{2}$, Math. Ann. 125 (1952), 165-171.

[9] A. Erdélyi, W. Magnus, F. Oberhettinger and F. G. Tricomi, Tables of Integral Transforms, Vol. I, McGraw-Hill Book Company, New York, Toronto and London, 1954.

[10] É. L. Mathieu, Traité de Physique Mathématique, VI-VII: Théory de l'Élasticité des Corps Solides (Part 2), Gauthier-Villars, Paris, 1890.

[11] C. H. Kimberling, A probabilistic interpretation of complete monotonicity, Aequationes Math. 10 (1974), 152-164.

[12] L. LANDAU, Monotonicity and bounds on Bessel functions, in: H. Warchall (Ed.), Proceedings of the Symposium on Mathematical Physics and Quantum Field Theory (Berkeley, California; June 11-13, 1999), Electron. J. Diff. Equ. 4 (2000), 147-144.

[13] A. LAFORGIA AND P. NATALINI, Turán type inequalities for some special functions, J. Inequal. Pure Appl. Math. 7 (1) (2006), Article ID 32, 1-3 (electronic).

[14] S. MinaKshisundaram And O. SZÁsz, On absolute convergence of multiple Fourier series, Trans. Amer. Math. Soc. 61 (1947), 36-53.

[15] T. K. PogÁny And H. M. SRIVAstava, Some Mathieu-type series associated with the Fox-Wright function, Comput. Math. Appl. 57 (2009), 127-140.

[16] T. K. Pogány, H. M. Srivastava And Ž. Tomovski, Some families of Mathieu a-series and alternating Mathieu a-series, Appl. Math. Comput. 173 (2006), 69-108. 
[17] K. SCHRÖDER, Das Problem der eingespannten rechteckigen elastischen Platte I.: Die biharmonische Randwertaufgabe für das Rechteck, Math. Anal. 121 (1949), 247-326.

[18] H. M. SRIVAStAVA AND J. ChOI, Zeta and q-Zeta Functions and Associated Series and Integrals, Elsevier Science Publishers, Amsterdam, London and New York, 2012.

[19] H. M. SRIVAstaVA AND Ž. Tomovski, Some problems and solutions involving Mathieu series and its generalizations, JIPAM J. Inequal. Pure Appl. Math. 5 (2) (2004), Article ID 45, 1-13 (electronic).

[20] H. M. SRIVAstava, Ž. Tomovski And D. LeSkovŠKI, Some families of Mathieu type series and Hurwitz-Lerch Zeta functions and associated probability distributions, Appl. Comput. Math. 14 (2015), 349-380.

[21] Ž. Tomovski And T. K. PogÁny, New upper bounds for Mathieu-types series, Banach J. Math. Anal. 3 (2) (2009), 9-15.

[22] Ž. TomOVSKI AND K. MehreZ, Some families of generalized Mathieu-type power series, associated probability distributions and related functional inequalities involving complete monotonicity and logconvexity, Math. Inequal. Appl. 20 (2017), 973-986.

[23] G. N. WATson, A Treatise on the Theory of Bessel Functions, Second edition, Cambridge University Press, Cambridge, London and New York, 1944.

[24] D. V. WidDER, The Laplace Transform, Princeton University Press, Princeton, 1941. 